\title{
Nocardioides daejeonensis sp. nov., a denitrifying bacterium isolated from sludge in a sewage- disposal plant
}

\section{Correspondence \\ Myungjin Lee \\ mgeneli@nate.com}

\author{
Sung-Geun Woo, ${ }^{1,2}$ Sathiyaraj Srinivasan, ${ }^{1,3}$ Jihoon Yang, ${ }^{1,2}$ \\ Yong-An Jung, ${ }^{4}$ Myung Kyum $\mathrm{Kim}^{3}$ and Myungjin Lee ${ }^{1}$
}

\footnotetext{
${ }^{1}$ Research and Development Division, H-Plus Eco Ltd, BVC 301, Korea Research Institute of Bioscience and Biotechnology (KRIBB), Eoeun-dong, Yuseong-gu, Daejeon 305-333, Republic of Korea

${ }^{2}$ School of Civil and Environmental Engineering, Yonsei University, Seoul 120-749, Republic of Korea

${ }^{3}$ Department of Bio and Environmental Technology, Division of Environmental and Life Science, College of Natural Science, Seoul Women's University, 623 Hwarangno, Nowon-gu, Seoul 139-774, Republic of Korea

${ }^{4}$ Korea Testing Certification, Chemical Industry Team, 587-10, Sinsa-Dong, Gangnam-Gu, Seoul, Republic of Korea
}

The genus Nocardioides was first described by Prauser (1976) with a single species, Nocardioides albus. At the time of writing, the genus Nocardioides comprised 51 species, many of which were isolated from soils from different parts of the world (Prauser, 1976, 1984; O'Donnell et al., 1982; Suzuki \& Komagata, 1983). In the course of investigating the micro-organisms in the sludge at a sewage-disposal plant in South Korea, a Gram-reaction-positive, nonmotile, aerobic bacterium, strain MJ31 ${ }^{\mathrm{T}}$, was isolated. The

Abbreviations: DPG, diphosphatidylglycerol; PE, phosphatidylethanolamine; $P G$, phosphatidylglycerol.

The GenBank/EMBL/DDBJ accession number for the 16S rRNA gene sequence of strain MJ31 $1^{\top}$ is JF937066.

A supplementary table and three supplementary figures are available with the online version of this paper. taxonomic position of this bacterium has now been investigated using a polyphasic approach.

Strain $\mathrm{MJ} 31^{\mathrm{T}}$ was isolated from sludge at the Daejeon sewage-disposal plant in South Korea. For the isolation, $1 \mathrm{~g}$ fresh sludge was mixed with $50 \mathrm{ml}$ saline $[0.85 \%(\mathrm{w} / \mathrm{v})$ $\mathrm{NaCl}$ ], vortexed and serially diluted. A $100 \mu \mathrm{l}$ sample of each dilution was then spread onto $0.1 \times \mathrm{R} 2 \mathrm{~A}$ agar (Difco) and incubated at $30{ }^{\circ} \mathrm{C}$ for 1 week. Single colonies of strain $\mathrm{MJ} 31^{\mathrm{T}}$ were transferred onto fresh plates and the purified colonies were tentatively identified by analysis of partial $16 \mathrm{~S}$ rRNA gene sequences. The isolate was routinely cultured on nutrient agar (NA; Difco) at $30^{\circ} \mathrm{C}$ and preserved, as a suspension in Luria-Bertani broth (LB broth; Difco) with $20 \%(\mathrm{w} / \mathrm{v})$ glycerol, at $-70{ }^{\circ} \mathrm{C}$.

Cell morphology and motility were observed under a light microscope (BH2; Olympus) and a transmission electron 
microscope (LEO912AB; Carl Zeiss), using cells grown for $24 \mathrm{~h}$ in nutrient broth at $30{ }^{\circ} \mathrm{C}$. For electron microscopy, cells were gently resuspended in a drop of deionized water, placed on a carbon- and Formvar-coated nickel grid and allowed to settle for $30 \mathrm{~s}$, before the grid was floated on a drop of $0.1 \%(\mathrm{w} / \mathrm{v})$ aqueous uranyl acetate, blotted dry and then viewed at $100 \mathrm{kV}$. The Gram reaction was performed using the non-staining $(\mathrm{KOH})$ method, as described by Buck (1982). Catalase activity was assessed by bubble production in $3 \%(\mathrm{v} / \mathrm{v}) \mathrm{H}_{2} \mathrm{O}_{2}$ and oxidase activity was assessed using $1 \%(\mathrm{w} / \mathrm{v})$ tetramethyl $p$-phenylenediamine (Cappuccino \& Sherman, 2002). Anaerobic growth was examined in serum bottles, using nutrient broth with sodium thioglycolate $\left(\mathrm{g} \mathrm{l}^{-1}\right)$ and replacing the air in the bottles with nitrogen.

Physiological characteristics were determined by using the API 20NE, API ID $32 \mathrm{GN}$ and API ZYM galleries (bioMérieux) according to the manufacturer's instructions. Growth at $4,10,20,25,28,30,35,37,40,42$ and $45{ }^{\circ} \mathrm{C}$ and $\mathrm{pH} 3.0-12.0$ (at intervals of $0.5 \mathrm{pH}$ unit) was assessed in LB broth for 5 days. The $\mathrm{pH}$ of the medium was adjusted using diluted $\mathrm{NaOH}$ or $\mathrm{HCl}$. Salt tolerance was tested in R2A broth supplemented with $0-15 \%(w / v) ~ N a C l$, with incubation for 5 days at $30{ }^{\circ} \mathrm{C}$. Growth on trypticase soy agar (TSA; Difco), R2A agar and LB agar was also evaluated at $30{ }^{\circ} \mathrm{C}$. Most of the phenotypic characteristics of strain $\mathrm{MJ} 31^{\mathrm{T}}$ are given in the species description; those that differentiated strain $\mathrm{MJ} 31^{\mathrm{T}}$ from closely related type strains are listed in Table 1.

The genomic DNA of the novel strain was extracted and purified as described by Moore \& Dowhan (1995) and then enzymatically degraded into nucleosides so that its $\mathrm{G}+\mathrm{C}$ content could be determined as described by Mesbah et al. (1989) using reverse-phase HPLC. Isoprenoid quinones were extracted with chloroform/methanol $(2: 1$, v/v), evaporated under vacuum and re-extracted in $n$-hexane/ water $(1: 1, \mathrm{v} / \mathrm{v})$. The crude $\mathrm{n}$-hexane/quinone solution was purified using Sep-Pak Vac silica cartridges (Waters) and subsequently analysed by HPLC as previously described (Hiraishi et al., 1996). In order to perform fatty acid methyl ester analysis, strain MJ31 and closely related type strains were grown on TSA for $48 \mathrm{~h}$ at $30^{\circ} \mathrm{C}$. Two loopfuls of bacterial mass of each strain were collected and subjected to saponification, methylation and extraction using the methods of Kuykendall et al. (1988). The fatty acid methyl ester mixtures were separated using version 6.0 of the Sherlock Microbial Identification System (MIDI), analysed by GC (6890; Hewlett Packard) and identified with the Microbial Identification software package (Sasser, 1990). To determine the polar lipid profile of strain MJ31 ${ }^{\mathrm{T}}$, the strain's total cellular polar lipids were extracted and examined by two-dimensional TLC (Minnikin et al., 1977).

Extraction of genomic DNA was performed with a commercial genomic DNA extraction kit (Solgent) before PCRmediated amplification of the 16S rRNA gene and sequencing of the purified PCR product were carried out according to
Kim et al. (2005). Full sequences of the 16S rRNA gene were compiled using SeqMan software (DNASTAR). The 16S rRNA gene sequences of related taxa were obtained from GenBank. Multiple alignments were performed using the CLUSTAL_X program (Thompson et al., 1997). Gaps were edited in the BioEdit program (Hall, 1999) and evolutionary distances were calculated using the Kimura two-parameter model (Kimura, 1983). Phylogenetic trees were then constructed using the neighbour-joining (Saitou \& Nei, 1987) and maximum-parsimony (Fitch, 1971) algorithms in the MEGA3 program (Kumar et al., 2004). To obtain confidence levels for the branches of these trees, bootstrap analyses were conducted, with 1000 replicates (Felsenstein, 1985). A maximum-likelihood tree was also constructed, using the PHYLIP program (Choi et al., 2000; Brinkman et al., 2001).

DNA-DNA hybridization was performed fluorometrically, according to the method developed by Ezaki et al. (1989), using photobiotin-labelled DNA probes and micro-dilution wells. The hybridizations were carried out reciprocally, with five replications per sample. The highest and lowest values obtained for each sample were excluded and the remaining three values were utilized in the calculation of each of the mean relatedness values that are reported below.

The 16S rRNA gene sequence of the strain $\mathrm{MJ} 31^{\mathrm{T}}$ determined in this study, which was a continuous stretch of $1468 \mathrm{bp}$, appeared most similar to the corresponding sequences of Nocardioides dubius $\mathrm{KSL}^{-104^{\mathrm{T}}} \quad(98.6 \%$ sequence similarity), Nocardioides jensenii DSM $20641^{\mathrm{T}}$ (97.6\%), Nocardioides daedukensis MDN22 ${ }^{\mathrm{T}}(97.2 \%)$ and Nocardioides mesophilus MSL-22 ${ }^{\mathrm{T}}$ (97.0\%). Sequence similarities between the novel strain and other members of the genus Nocardioides or members of the genus Marmoricola were all $97.0 \%$ or lower. In the neighbour-joining phylogenetic tree (Fig. 1) strain $\mathrm{MJ} 31^{\mathrm{T}}$ was clustered with $N$. dubius KSL-104 ${ }^{\mathrm{T}}$ (with a bootstrap value of $97 \%$ ), close to species of Marmoricola and N. mesophilus MSL-22 ${ }^{\mathrm{T}}$. In the maximum-parsimony and maximum-likelihood trees (Figs S1 and S2, available in IJSEM Online), strain $\mathrm{MJ} 31^{\mathrm{T}}$ was again clustered with $N$. dubius KSL-104 ${ }^{\mathrm{T}}$ but this cluster was closer to most other members of the genus Nocardioides than to species of Marmoricola.

The results obtained from the chemotaxonomic analyses were in agreement with the results of phylogenetic inference, indicating that strain $\mathrm{MJ} 31^{\mathrm{T}}$ belongs to the genus Nocardioides. The major menaquinone detected for this strain was MK-8 $\left(\mathrm{H}_{4}\right)$. The overall fatty acid composition of strain $\mathrm{MJ}_{31}{ }^{\mathrm{T}}$ (Table S1) was very similar to those of other members of the genus Nocardioides, being dominated by large amounts of iso-branched and unsaturated fatty acids, particularly iso- $\mathrm{C}_{16: 0}(34.7 \%)$, iso- $\mathrm{C}_{17: 0}(15.4 \%)$ and $\mathrm{C}_{18: 1} \omega 9 c(11.6 \%)$. However, there were some qualitative and quantitative differences in the fatty acid contents of the novel strain and the closely related type strains. For example, although all the closely related type strains of Nocardioides species included in Table $\mathrm{S} 1$ contained iso- $\mathrm{C}_{14: 0}, \mathrm{C}_{18: 1} \omega 7 \mathrm{c}$ and $\mathrm{C}_{16: 0} 2-\mathrm{OH}$, none of these fatty acids was detected in 
Table 1. Some selective phenotypic characteristics of strain $\mathrm{MJ} 31^{\top}$ and the type strains of related Nocardioides species

Strains: 1, MJ31 ${ }^{\mathrm{T}}$; 2, N. alkalitolerans KCTC $19037^{\mathrm{T}}$; 3, N. daedukensis KCTC 19601 ${ }^{\mathrm{T}}$; 4, N. dubius KCTC 9992 ${ }^{\mathrm{T}}$; 5, N. jensenii KCTC $9134^{\mathrm{T}}$; 6 , N. mesophilus KCTC $19310^{\mathrm{T}} ; 7$, N. salarius DSM $18239^{\mathrm{T}}$. All data were obtained in the present study. +, Positive reaction; -, negative reaction; w, weakly positive reaction.

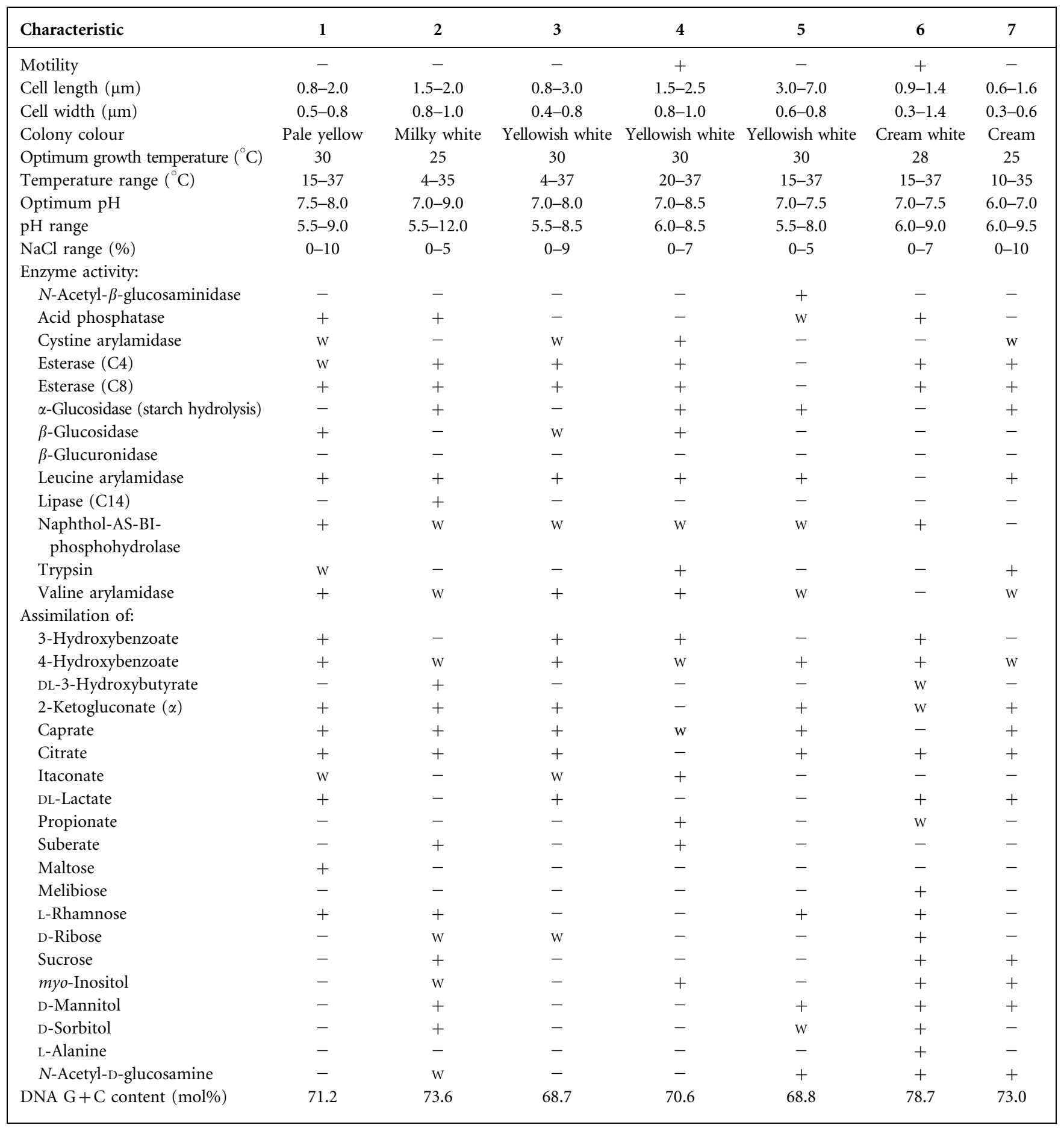

strain $\mathrm{MJ} 31^{\mathrm{T}}$. In terms of their fatty acids, strain $\mathrm{MJ} 31^{\mathrm{T}}$ and the type strains of Nocardioides species included in Table S1 were, however, clearly distinguishable from the type strains of Marmoricola aurantiacus (the type species of the genus Marmoricola) and Marmoricola bigeumensis.
Total lipids were observed in TLC after staining with 5\% ethanolic molybdophosphoric acid and ninhydrin reagent or with Zinzadze reagent (Fig. S3). Strain $\mathrm{MJ} 31^{\mathrm{T}}$ contained major amounts of diphosphatidylglycerol (DPG), moderate amounts of phosphatidylethanolamine (PE) and 


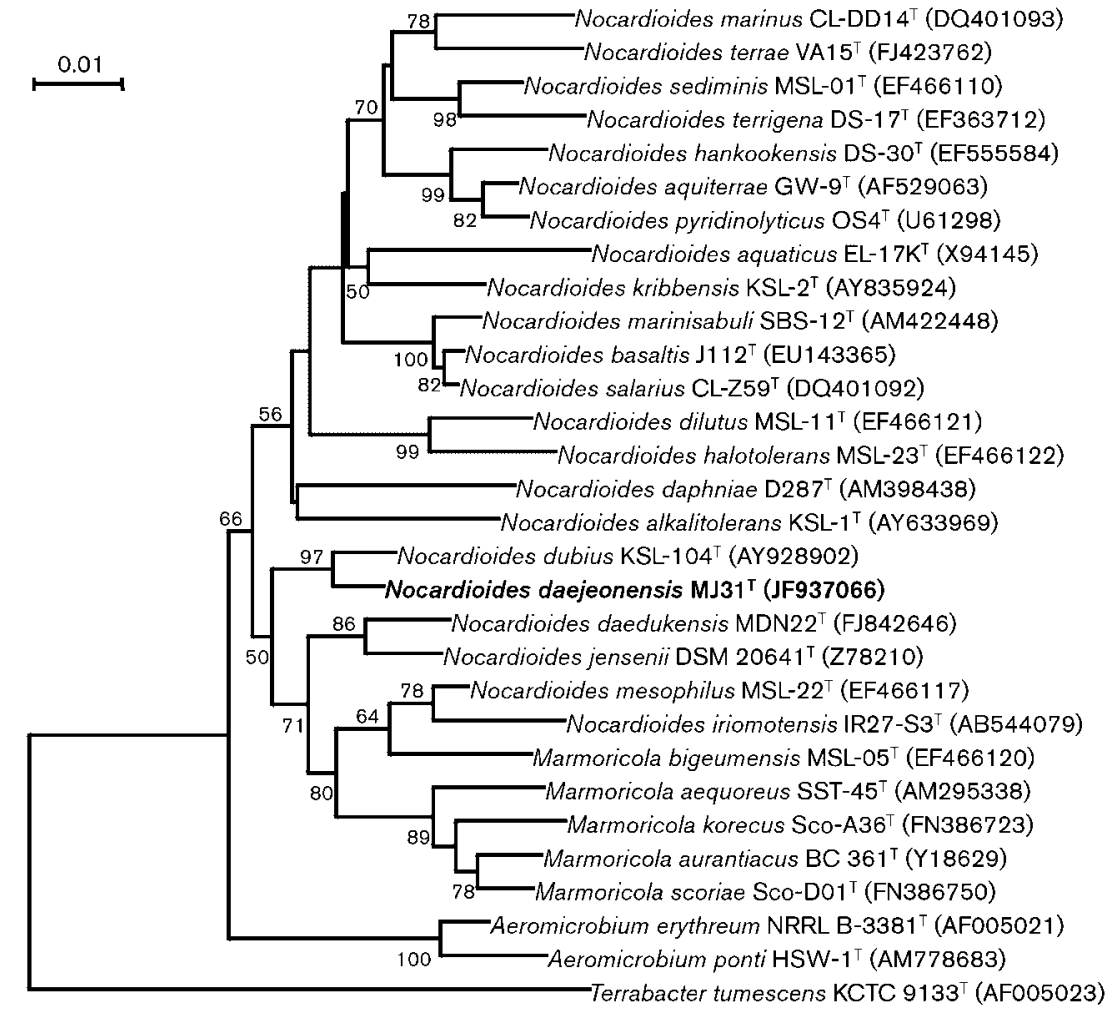

Fig. 1. Neighbour-joining phylogenetic tree based on 16S rRNA gene sequences, showing the relationships between strain $\mathrm{MJ}_{3} 1^{\top}$, Nocardioides species and other related genera. Percentage bootstrap values $>50 \%$ (based on 1000 replications) are shown at branch points. Terrabacter tumescens ATCC $6947^{\top}$ was used as an outgroup. Bar, 0.01 substitutions per nucleotide position. phosphatidylglycerol (PG) and minor amounts of two unknown phospholipids (PL1 and PL2). The polar lipid profile of strain $\mathrm{MJ} 31^{\mathrm{T}}$ was similar to those of established Nocardioides species (Yoon et al., 2010). The genomic DNA $\mathrm{G}+\mathrm{C}$ content of strain $\mathrm{MJ} 31^{\mathrm{T}}$ was $71.2 \mathrm{~mol} \%$.

To differentiate strain $\mathrm{MJ} 31^{\mathrm{T}}$ from the closely related Nocardioides species, DNA-DNA hybridizations were performed. Strain $\mathrm{MJ} 31^{\mathrm{T}}$ exhibited relatively low DNA-DNA relatedness values with Nocardioides alkalitolerans KCTC $19037^{\mathrm{T}}$ (7.5\%), N. daedukensis KCTC $19601^{\mathrm{T}}(18.2 \%), N$. dubius KCTC $9992^{\mathrm{T}}(28.2 \%)$, N. jensenii KCTC $9134^{\mathrm{T}}$ $(24.0 \%)$, N. mesophilus KCTC $19310^{\mathrm{T}} \quad(14.6 \%)$ and Nocardioides salarius DSM $18239^{\mathrm{T}}(8.8 \%)$. These results indicated that strain $\mathrm{MJ} 31^{\mathrm{T}}$ is not related to any established species in the genus Nocardioides (Wayne et al., 1987).

There is insufficient taxonomic evidence currently available to differentiate several Nocardioides species from the members of the genus Marmoricola (Yoon et al., 2005; Yamamura et al., 2011). In the present study, however, strain $\mathrm{MJ} 31^{\mathrm{T}}$ and the type strains of closely related Nocardioides species could be differentiated from members of the genus Marmoricola by their fatty acid profiles (Table S1) and by having rod/coccoid life cycles. It was possible to differentiate strain $\mathrm{MJ} 31^{\mathrm{T}}$ from the type strains of closely related species by using several phenotypic and chemotaxonomic characteristics. In addition, in the phylogenetic trees constructed using the maximum-parsimony and maximumlikelihood algorithms (Figs S1 and S2), strain $\mathrm{MJ} 31^{\mathrm{T}}$ formed a monophyletic clade with $N$. dubius and this clade formed part of a coherent phylogenetic cluster with most other members of the genus Nocardioides. Based on this evidence, both strain $\mathrm{MJ} 31^{\mathrm{T}}$ and $N$. dubius belong to the genus Nocardioides and not to the genus Marmoricola.

On the basis of the phylogenetic, genetic, phenotypic and chemotaxonomic data presented, strain $\mathrm{MJ} 31^{\mathrm{T}}$ represents a novel species in the genus Nocardioides, for which the name Nocardioides daejeonensis sp. nov. is proposed.

\section{Description of Nocardioides daejeonensis sp. nov.}

Nocardioides daejeonensis (da.e.je.on.en'sis. N.L. masc. adj. daejeonensis of or pertaining to Daejeon, the city in South Korea where the type strain was isolated).

Cells are Gram-reaction-positive, aerobic, non-motile and rod-shaped, measuring about $0.5-0.8 \mu \mathrm{m}$ in width and $0.8-2.0 \mu \mathrm{m}$ in length. Cells showed rod-to-coccus morphogenesis between the early exponential phase and stationary phase. Colonies grown on NA for 2 days are circular, raised, smooth, and pale yellow in colour. Growth occurs at $15-37{ }^{\circ} \mathrm{C}$ (optimum about $30{ }^{\circ} \mathrm{C}$ ), at $\mathrm{pH}$ values of 5.5-9.0 (optimum between 7.5 and 8.0), and in the presence of $0-10 \%(\mathrm{w} / \mathrm{v}) \mathrm{NaCl}$ (optimum, $2 \%$ ). Oxidasenegative and catalase-positive. Positive (API 20NE) for nitrate and nitrite reduction and aesculin hydrolysis but negative for indole production, acid production from glucose and arginine dihydrolase, urease and gelatinase activities. In API 20NE and API 32GN tests, L-arabinose, caprate, citrate, 
3-hydroxybenzoate, 4-hydroxybenzoate, 2-ketogluconate, DL-lactate, maltose, malonate, L-rhamnose and L-serine are utilized but $\mathrm{N}$-acetyl-D-glucosamine, adipate, L-alanine, L-fucose, gluconate, D-glucose, glycogen, L-histidine, 3hydroxybutyrate, 5-ketogluconate, malate, D-mannose, Dmannitol, melibiose, myo-inositol, phenylacetate, L-proline, propionate, D-ribose, salicin, D-sorbitol, suberate, sucrose and $n$-valerate are not. Positive (API ZYM) for acid phosphatase, alkaline phosphatase, esterase lipase (C8), leucine arylamidase, $\beta$-glucosidase, valine arylamidase and naphthol-AS-BI-phosphohydrolase, cystine arylamidase (weak), esterase (C4) (weak) and trypsin (weak) activities but negative for acetyl- $\beta$-glucosaminidase, $\alpha$-chymotrypsin, $\alpha$-fucosidase, $\alpha$-galactosidase, $\beta$-galactosidase, $\beta$-glucuronidase, $\alpha$-glucosidase, $N$ - $\alpha$-mannosidase and lipase (C14). The cell-wall peptidoglycan is based on LL-2-6-diaminopimelic acid and MK- $8\left(\mathrm{H}_{4}\right)$ is the predominant menaquinone. The major cellular fatty acids are iso- $\mathrm{C}_{16: 0}$, iso- $\mathrm{C}_{17: 0}$ and $\mathrm{C}_{18: 1} \omega 9 c$. The polar lipid profile contains major amounts of DPG and moderate amounts of PE and PG.

The type strain, MJ $31^{\mathrm{T}}\left(=\mathrm{KCTC} 19772^{\mathrm{T}}=\mathrm{JCM} 16922^{\mathrm{T}}\right)$, was isolated from sludge at the Daejeon sewage-disposal plant. The genomic DNA G $+\mathrm{C}$ content of the type strain is $71.2 \mathrm{~mol} \%$.

\section{Acknowledgements}

This work was supported by the GAIA Project (grant 173-101-034) of the Ministry of Environment, Republic of Korea.

\section{References}

Brinkman, F. S., Wan, I., Hancock, R. E., Rose, A. M. \& Jones, S. J. (2001). PhyloBLAST: facilitating phylogenetic analysis of BLAST results. Bioinformatics 17, 385-387.

Buck, J. D. (1982). Nonstaining (KOH) method for determination of Gram reactions of marine bacteria. Appl Environ Microbiol 44, 992-993.

Cappuccino, J. G. \& Sherman, N. (2002). Microbiology: a Laboratory Manual, 6th edn. Menlo Park, CA: Benjamin Cummings.

Choi, J. H., Jung, H. Y., Kim, H. S. \& Cho, H. G. (2000). PhyloDraw: a phylogenetic tree drawing system. Bioinformatics 16, 1056-1058.

Ezaki, T., Hashimoto, Y. \& Yabuuchi, E. (1989). Fluorometric deoxyribonucleic acid-deoxyribonucleic acid hybridization in microdilution wells as an alternative to membrane filter hybridization in which radioisotopes are used to determine genetic relatedness among bacterial strains. Int J Syst Bacteriol 39, 224-229.

Felsenstein, J. (1985). Confidence limit on phylogenies: an approach using the bootstrap. Evolution 39, 783-791.

Fitch, W. M. (1971). Toward defining the course of evolution: minimum change for a specific tree topology. Syst Zool 20, 406-416.

Hall, T. A. (1999). BioEdit: a user-friendly biological sequence alignment editor and analysis program for Windows 95/98/NT. Nucleic Acids Symp Ser 41, 95-98.

Hiraishi, A., Ueda, Y., Ishihara, J. \& Mori, T. (1996). Comparative lipoquinone analysis of influent sewage and activated sludge by highperformance liquid chromatography and photodiode array detection. J Gen Appl Microbiol 42, 457-469.
Kim, M. K., Im, W.-T., Ohta, H., Lee, M. \& Lee, S.-T. (2005). Sphingopyxis granuli sp. nov., a $\beta$-glucosidase-producing bacterium in the family Sphingomonadaceae in $\alpha-4$ subclass of the Proteobacteria. J Microbiol 43, 152-157.

Kimura, M. (1983). The Neutral Theory of Molecular Evolution. Cambridge: Cambridge University Press.

Kumar, S., Tamura, K. \& Nei, M. (2004). MEGA3: integrated software for molecular evolutionary genetics analysis and sequence alignment. Brief Bioinform 5, 150-163.

Kuykendall, L. D., Roy, M. A., O’Neill, J. J. \& Devine, T. E. (1988). Fatty acids, antibiotic resistance and deoxyribonucleic acid homology groups of Bradyrhizobium japonicum. Int J Syst Bacteriol 38, 358-361.

Mesbah, M., Premachandran, U. \& Whitman, W. B. (1989). Precise measurement of the $\mathrm{G}+\mathrm{C}$ content of deoxyribonucleic acid by high-performance liquid chromatography. Int J Syst Bacteriol 39, 159-167.

Minnikin, D. E., Patel, P. V., Alshamaony, L. \& Goodfellow, M. (1977). Polar lipid composition in the classification of Nocardia and related bacteria. Int J Syst Bacteriol 27, 104-117.

Moore, D. D. \& Dowhan, D. (1995). Preparation and Analysis of DNA. In Current Protocols in Molecular Biology, pp. 2-11. Edited by F. W. Ausubel, R. Brent, R. E. Kingston, D. D. Moore, J. G. Seidman, J. A. Smith \& K. Struhl. New York: Wiley.

O’Donnell, A. G., Goodfellow, M. \& Minnikin, D. E. (1982). Lipids in the classification of Nocardioides: reclassification of Arthrobacter simplex (Jensen) Lochhead in the genus Nocardioides (Prauser) emend. O'Donnell et al. as Nocardioides simplex comb. nov. Arch Microbiol 133, 323-329.

Prauser, H. (1976). Nocardioides, a new genus of the order Actinomycetales. Int J Syst Bacteriol 26, 58-65.

Prauser, H. (1984). Nocardioides luteus spec. nov. Z Allg Mikrobiol 24, 647-648.

Saitou, N. \& Nei, M. (1987). The neighbor-joining method: a new method for reconstructing phylogenetic trees. Mol Biol Evol 4, 406425.

Sasser, M. (1990). Identification of bacteria by gas chromatography of cellular fatty acids, MIDI Technical Note 101. Newark, DE: MIDI Inc.

Suzuki, K. \& Komagata, K. (1983). Pimelobacter gen. nov., a new genus of coryneform bacteria with LL-diaminopimelic acid in the cell wall. J Gen Appl Microbiol 29, 59-71.

Thompson, J. D., Gibson, T. J., Plewniak, F., Jeanmougin, F. \& Higgins, D. G. (1997). The CLUSTAL_X windows interface: flexible strategies for multiple sequence alignment aided by quality analysis tools. Nucleic Acids Res 25, 4876-4882.

Wayne, L. G., Brenner, D. J., Colwell, R. R., Grimont, P. A. D., Kandler, O., Krichevsky, M. I., Moore, L. H., Moore, W. E. C., Murray, R. G. E. \& other authors (1987). International Committee on Systematic Bacteriology. Report of the ad hoc committee on reconciliation of approaches to bacterial systematics. Int $J$ Syst Bacteriol 37, 463-464.

Yamamura, H., Ohkubo, S. Y., Nakagawa, Y., Ishida, Y., Hamada, M., Otogturo, M., Tamura, T. \& Hayakawa, M. (2011). Nocardioides iriomotensis sp. nov., an actinobacterium isolated from a forest soil. Int J Syst Evol Microbiol 61, 2205-2209.

Yoon, J. H., Lee, C. H. \& Oh, T. K. (2005). Nocardioides dubius sp. nov., isolated from an alkaline soil. Int J Syst Evol Microbiol 55, 2209-2212.

Yoon, J. H., Park, S., Jang, S. J., Lee, J. S., Lee, K. C. \& Oh, T. K. (2010). Nocardioides daedukensis sp. nov., a halotolerant bacterium isolated from soil. Int J Syst Evol Microbiol 60, 1334-1338. 